\title{
Serum Hepcidin Concentration in Relation to Iron Deficiency in Ain Shams Athletes
}

\author{
AHMED N. HASSAN, P.*; DINA A. MOHAMED, A.P.**; YASMIN M. ABOU ELELA, M.D.* and \\ SARA A. AHMED, M.D. ***
}

The Departments of Clinical Pharmacology*, Clinical Pathology \& Immunology** and

Clinical Pharmacology \& Clinical Nutrition***, Faculty of Medicine, Ain Shams University

\begin{abstract}
Background: Iron deficiency is a frequent and multifactorial disorder in the career of athletes. Exercise-induced disturbances in iron homeostasis produce deleterious effects on performance and adaptation to training. Thus, the identification of strategies that restore or maintain iron homeostasis in athletes is required.
\end{abstract}

Aim of Study: To determine the relation between regular physical activity, iron level and hepcidin level as well as inflammatory markers among a sample of Medical Ain Shams University Students.

Subjects and Methods: The current study is a descritptive study of 54 students from 200 students that follow regular physical activity among 1220 Ain Shams Medical Students. Our study group was divided into two groups. Group 1 included 23 students with reduced serum iron level. Group 2 included 31 students with reduced serum iron level.

Results: There was no significant difference observed between studied groups regarding BMI, waist circumference, hip circumference and waist hip ratio and the hemoglobin level. However serum ferritin and hepcidin were significantly lower in reduced serum iron group than normal serum iron group. CRP was significantly higher in reduced serum iron group than normal serum iron group and shows positive correlation between with BMI in reduced serum iron whereas hepcidin show significant positive correlation between serum hepcidin and waist circumference in reduced serum iron group as well as significant negative correlation with BMI in control group.

Conclusion: The timing of sampling post exercise may show the induction of hepcidin response to exercise which may show guiding information on exact timing with iron therapy in athletes.

Key Words: Iron-Hepcidin - Nutrition - CRP-Athletes.

Correspondence to: Dr. Sara A.

Ahmed,E-Mail: drsara_khedr@med.asu.

A d n $\cdots$

\section{Introduction}

IRON deficiency is one of the most prevalent nutritional disturbances in the world. Exercise has been shown to play a regulative role in iron metabolism. In fact, the prevalence of iron deficiency is higher in physically active individuals and athletes, in comparison to the sedentary population

[1].

Iron is an essential component of hemoglobin and myoglobin, which ensures oxygen supply to the skeletal muscle. In the myocyte, iron is a component of several mitochondrial proteins that are integral parts of the electron transport chain, and facilitate the activation of oxidative phosphorylation. Hence, the deficiency of this mineral may compromise the energy metabolism system by increasing the contribution of glycolysis and reducing energy efficiency, performance and adaptations to training [2].

Due to the significant role of iron in optimal physical performance and health, the evaluation of iron status in athletes is of great importance in order to prevent iron deficiency Iron deficiency progresses in three stages: In the first stage iron stores in bone marrow, liver, and spleen are depleted; in the second stage, erythropoiesis decreases; in the final stage haemoglobin production falls resulting in anemia [3].

Recently, the mechanisms relating to iron deficiency in athletes have been increasingly investigated, with a shift in focus from the more traditionally accepted avenues of exercise-induced iron loss such as hemolysis, sweating and gastrointestinal bleeding to the influence of the iron regulatory

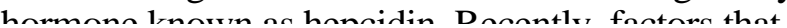


may affect the activity of this hormone such as training frequency, exercise modality and nutritional practices have been established [4].

Hepcidin is a peptide hormone produced mainly by hepatocytes. The main function of hepcidin is related to immunity since iron is essential for the survival of invading pathogens. Hepcidin regulates iron by hindering its absorption. Thus, it seems that both iron deficiency and iron overload are influenced to a large extent by an individual's hepcidin response [2].

Inflammation can be determined by acute phase reactants including CRP and ferritin. The level of physical activity is correlated to inflammatory markers. Some types of physical activity are accompanied by inflammation-like reactions that can induce an acute phase response and increased ferritin levels which is an acute phase reactant. In case of exercise-induced inflammation, normal ferritin levels could be deceptive, reflecting rather an acute phase response than the true efficiency of athletes iron stores. Estimation of iron status depends on the determination of all iron parameters [5].

\section{Subjects and Methods}

Type of study: Descriptive study.

Study setting: The study was conducted at Ain Shams University (ASU) Hospitals.

Study period: 3 months, onset in September 2017.

Sampling method: This study was performed on simple random sample.

Sample size: 54 athletes were included in this study.

Age: Age group ranges from 19 to 24 years.

Gender: No sex predilection.

Inclusion criteria: Medical students who voluntarily participated in the study and do perform any sort of physical activity.

Exclusion criteria: Individuals with history of disease that might affect iron status and inflammation including, obesity, infection, diabetes mellitus or prediabetes and smoking or taking supplements. Auto immune diseases also affect inflammatory state as rheumatoid arthritis and systemic lupus or chronic disorders like anemia.
Consent: A written informed consent was obtained from each student after explaining the aim of the study \& all the procedures that were done. Privacy \& confidentiality were concerned. Approval was obtained from the ethical committee. The study was conducted according to the stipulations of the ASU ethical and scientific committee.

Study method: Convenience sample.

\section{Study tools:}

Using the data supplied by the participants project.

Physical examination: Anthropometric data: Weight, height, Body mass index, waist, waist hip ratio.

Laboratory investigations: $\mathrm{CBC}$ was done using Medonic cell counter (BOULE MEDUCAL AB, Domnarvsgatan 4 SE-163 53 Spanga, M series, Sweden). Iron profile (iron, Total Iron Binding Capacity (TIBC) assesd using humalyzer 3000 ( Human) spectrophotometer. Ferritin was assessed using Enzyme Linked Immunosorbent Assay (ELISA) (Monobind Inc., USA). Hepcidin level was assessed using ELISA kit (Bioassay technology laboratory, China) [4].

\section{Statistical analysis:}

The collected data was coded, tabulated, and statistically analyzed using IBM SPSS statistics ( Statistical Package for Social Sciences) software version 22.0, IBM Corp., Chicago, USA, 2013 and Microsoft Office Excel 2007.

Descriptive statistics was done for quantitative data as minimum \& maximum of the range as well as mean $\pm \mathrm{SD}$ (standard deviation) for quantitative normally distributed data, median and 1 st \& 3rd inter-quartile range for quantitative non-normally distributed data, while it was done for qualitative data as number and percentage. Inferential analyses was done for quantitative variables using ShapiroWilk test for normality testing, independent $t$-test in cases of two independent groups with normally distributed data and Mann whiteny $U$ in cases of two independent groups with non-normally distributed data. In qualitative data, inferential analyses for independent variables was done using Chi square test for differences between proportions. While correlations was done using spearman rho test for numerical non normally distributed and qualitative data. Linear regression model was used to find out independent factors affecting serum hepcidin. The level of significance was taken at $p$-value $<0.050$ is significant, otherwise is nonsignificant. 


\section{Results}

Statistical results:

Descriptive statistics of the studied subjects:

Table (1): Demographic and anthropometric characteristics of studied groups.

\begin{tabular}{lccc}
\hline Items & $\begin{array}{c}\text { Reduced } \\
\text { serum } \\
\text { iron group } \\
(\mathrm{N}=23)\end{array}$ & $\begin{array}{c}\text { Normal } \\
\text { serum } \\
\text { iron group } \\
(\mathrm{N}=31)\end{array}$ & $\begin{array}{c}p \text { - } \\
\text { value }\end{array}$ \\
\hline Age (years): & $21.9 \pm 1.3$ & $21.8 \pm 1.4$ & 0.708 \\
$\quad$ Mean $\pm \mathrm{SD}$ & $19.0-23.0$ & $19.0-24.0$ & \\
$\quad$ Range & & & \\
BMI $\left(\mathrm{kg} / \mathrm{m}^{2}\right):$ & $24.2 \pm 3.0$ & $23.9 \pm 3.2$ & 0.712 \\
$\quad$ Mean $\pm \mathrm{SD}$ & $18.2-30.4$ & $19.0-28.9$ & \\
$\quad$ Range & & & \\
Waist circumference $(\mathrm{cm}):$ & & & \\
Mean $\pm \mathrm{SD}$ & $82.1 \pm 8.6$ & $80.0 \pm 9.1$ & 0.395 \\
$\quad$ Range & $65.0-99.0$ & $62.0-99.0$ & \\
Hip circumference $(\mathrm{cm}):$ & & & \\
$\quad$ Mean $\pm \mathrm{SD}$ & $102.2 \pm 7.9$ & $100.3 \pm 8.1$ & 0.399 \\
$\quad$ Range & $85.0-117.0$ & $85.0-115.0$ & \\
Waist/hip ratio: & & & \\
$\quad$ Mean $\pm \mathrm{SD}$ & $0.80 \pm 0.06$ & $0.79 \pm 0.05$ & 0.526 \\
$\quad$ Range & $0.64-0.90$ & $0.67-0.95$ & \\
\hline
\end{tabular}

$\wedge$ : Independent $t$-test.

The study included 23 athletes in group 1 with mean age $21.9 \pm 1.3$ while group 2 included 31 athletes with mean age 21.8 \pm 1.4 . No significant difference was observed between both groups regarding BMI, WC, Hip circumference and WHr ( Table 1).

Table (2): Shows Hemoglobin (mg/dl) among the studied groups.

\begin{tabular}{lccc}
\hline Measure & $\begin{array}{c}\text { Reduced serum } \\
\text { iron group } \\
(\mathrm{N}=23)\end{array}$ & $\begin{array}{c}\text { Normal serum } \\
\text { iron group } \\
(\mathrm{N}=31)\end{array}$ & $\begin{array}{c}p \text { - } \\
\text { value }\end{array}$ \\
\hline $\begin{array}{l}\mathrm{Hb}: \\
\text { Mean } \pm \mathrm{SD}\end{array}$ & $12.7 \pm 1.7$ & $13.2 \pm 1.3$ & 0.382 \\
\hline
\end{tabular}

Table (2) shows no significant difference observed between both groups regarding the hemoglobin level with mean $12.7 \pm 1.7$ in group 1 versus $13.2 \pm 1.3$ in group 2 .

Table (3): Serum iron levels (mcg/dl) among studied groups.

\begin{tabular}{lccc}
\hline Measure & $\begin{array}{c}\text { Reduced serum } \\
\text { iron group } \\
(\mathrm{N}=23)\end{array}$ & $\begin{array}{c}\text { Normal serum } \\
\text { iron group } \\
(\mathrm{N}=31)\end{array}$ & $\begin{array}{c}p- \\
\text { value }\end{array}$ \\
\hline $\begin{array}{l}\text { Items } \\
\text { Mean } \pm \mathrm{SD}\end{array}$ & $41.3 \pm 5.3$ & $93.7 \pm 18.8$ & $<0.001^{*}$ \\
\hline A. Independent $t$-test. & & &
\end{tabular}

$\wedge$ : Independent $t$-test.
Table (3) shows a significant difference between studied groups regarding serum iron level with mean $41.3 \pm 5.3$ in group 1 versus mean $93.7 \pm$ 18.8 in group 2.

Table (4): Serum ferritin (ng/mL) levels among the studied groups.

\begin{tabular}{llll}
\hline Measure & $\begin{array}{c}\text { Reduced serum } \\
\text { iron group } \\
(\mathrm{N}=23)\end{array}$ & $\begin{array}{c}\text { Normal serum } \\
\text { iron group } \\
(\mathrm{N}=31)\end{array}$ & $\begin{array}{c}p \text { - } \\
\text { value }\end{array}$ \\
\hline Ferritin level: & & & \\
$\quad$ Median (IQR) & 10.5 & 47.5 & $<0.001 *$ \\
$\quad$ Range & $6.0-8.0$ & $8.4-220.0$ & \\
\hline : Mann Whitney test. & & &
\end{tabular}

^: Mann Whitney test.

Table (4) shows a significant difference between studied groups regarding serum ferritin level with median $10.5 \mathrm{ng} / \mathrm{ml}$ in group 1 versus median 47.5 $\mathrm{ng} / \mathrm{ml}$ in group 2 .

Table (5): Serum CRP among studied groups.

\begin{tabular}{llll}
\hline Measure & $\begin{array}{c}\text { Reduced serum } \\
\text { iron group } \\
(\mathrm{N}=23)\end{array}$ & $\begin{array}{c}\text { Normal serum } \\
\text { iron group } \\
(\mathrm{N}=31)\end{array}$ & $\begin{array}{c}p \text { - } \\
\text { value }\end{array}$ \\
\hline CRP level: & & & \\
$\quad$ Median (IQR) & 25.0 & 6.0 & $<0.001 *$ \\
Range & $7.0-110.0$ & $3.0-17.0$ & \\
\hline
\end{tabular}

^: Mann Whitney test.

Table (5) shows a significant difference between studied groups regarding serum CRP level with median $25 \mathrm{mg} / \mathrm{dl}$ in group 1 versus median $6 \mathrm{mg} / \mathrm{dl}$ in group 2 .

Table (6): Serum hepcidin level mcg/dl among the studied groups.

\begin{tabular}{llll}
\hline Measure & $\begin{array}{c}\text { Reduced serum } \\
\text { iron group } \\
(\mathrm{N}=23)\end{array}$ & $\begin{array}{c}\text { Normal serum } \\
\text { iron group } \\
(\mathrm{N}=31)\end{array}$ & $\begin{array}{c}p^{-} \\
\text {value }\end{array}$ \\
\hline Level: & & & \\
$\quad$ Median (IQR) & 1.4 & 2.3 & $0.046^{*}$ \\
Range & $0.2-6.5$ & $0.1-9.4$ & \\
$>55.0$ & $0(0.0 \%)$ & $0(0.0 \%)$ & \\
\hline
\end{tabular}

$\wedge$ : Independent $t$-test.

Table (6) shows a significant difference between studied groups regarding serum hepcidin level with median $1.4 \mathrm{mcg} / \mathrm{dl}$ in group 1 versus median 2 . $3 \mathrm{mcg} / \mathrm{dl}$ in group 2.

Table (7) show that there was significant positive correlation between serum hepcidin and waist circumference in reduced serum iron group as well as significant negative correlation with BMI in control group (normal serum iron group). 
Table (7): Correlations of serum hepcidin with studied parameters among the studied groups.

\begin{tabular}{lllll}
\hline Variables & $\begin{array}{c}\text { Reduced serum } \\
\text { iron group } \\
(\mathrm{N}=23)\end{array}$ & $\begin{array}{c}\text { Normal serum } \\
\text { iron group } \\
(\mathrm{N}=31)\end{array}$ \\
\cline { 2 - 6 } & \multicolumn{1}{c}{$r$} & $p$-value & $r$ & $p$-value \\
\hline Age & 0.168 & 0.444 & -0.104 & 0.578 \\
BMI & -0.070 & 0.751 & -0.425 & $0.017 *$ \\
Waist circumference & 0.430 & $0.041^{*}$ & -0.276 & 0.132 \\
Hip circumference & 0.393 & 0.063 & -0.304 & 0.096 \\
Waist/hip ratio & 0.367 & 0.085 & -0.108 & 0.565 \\
Hemoglobin & -0.316 & 0.142 & 0.123 & 0.509 \\
Serum iron & 0.170 & 0.438 & 0.085 & 0.650 \\
Serum ferritin & -0.204 & 0.349 & -0.189 & 0.308 \\
Serum CRP & 0.013 & 0.952 & 0.113 & 0.545 \\
\hline
\end{tabular}

Spearman correlation test

$r$ : Correlation coefficient.

*: Significant.

Table (8): Correlations of serum CRP with studied parameters among the tudied groups.

\begin{tabular}{lcccc}
\hline Variables & $\begin{array}{c}\text { Reduced serum } \\
\text { iron group } \\
(\mathrm{N}=23)\end{array}$ & $\begin{array}{c}\text { Normal serum } \\
\text { iron group } \\
(\mathrm{N}=31)\end{array}$ \\
\cline { 2 - 6 } & $r$ & $p$-value & $r$ & $p$-value \\
\hline Age & 0.355 & 0.096 & -0.343 & 0.059 \\
BMI & 0.635 & $0.001^{*}$ & 0.513 & $0.003^{*}$ \\
Waist circumference & 0.496 & $0.016^{*}$ & 0.499 & $0.004^{*}$ \\
Hip circumference & 0.052 & 0.813 & -0.184 & 0.322 \\
Waist/hip ratio & -0.186 & 0.395 & 0.049 & 0.795 \\
Hemoglobin & 0.286 & 0.186 & -0.131 & 0.482 \\
Serum iron & 0.199 & 0.364 & 0.159 & 0.392 \\
Serum ferritin & 0.267 & 0.219 & 0.098 & 0.601 \\
\hline Spearman correlation test. & & & & \\
$r$ : Correlation coefficient. & & & & \\
*: Significant. & & & &
\end{tabular}

Table (8) show that there was significant positive correlation between serum CRP and BMI regarding reduced serum iron group and control group.

\section{Discussion}

In this study, there was no significant difference between the two studied groups regarding demographic and anthropometric characteristics.

Our study revealed no difference in hemoglobin level between both studied groups. This is similar with the results of [6]. Our results were also with [ 7] that showed no difference in hemoglobin level between groups.

In our study, Serum ferritin was significantly lower among serum iron reduced group. In normal subjects, serum ferritin concentration correlates well with iron stores measured by the phlebotomy technique [8].
Serum levels of positive acute phase proteins including ferritin, C-reactive protein, and alpha1-acid glycoprotein rise dramatically as part of the inflammatory response mediated by increased expression of cytokines. Increased levels of serum ferritin as part of the acute phase response mean that's serum ferritin levels not only correlate with iron availability in the presence of inflammation. Assessment of patients' iron status becomes more complex under these conditions and requires wider awareness of iron homeostatic mechanisms [9]. In our study serum ferritin level was more influenced by iron stores than inflammatory state due to physical activity.

C-reactive protein is a sensitive marker of lowgrade systemic inflammation and a common index in clinical practice. Although BMI is accepted worldwide as an important index of obesity, it fails to distinguish the fat mass from fat-free mass or to represent the pattern of fat distribution. With the measurement of $\mathrm{WC}$ it was able to examine the association between the distributions of body fat [10].

Our results showed that both BMI and abdominal obesity indices (WC) were significantly and positively associated with plasma CRP that come in consistency with the results of [11].

Our study also showed Serum CRP level was significantly higher among serum iron reduced group. This result may prove that the systemic inflammatory state of this group is higher than the control group.

In the current study, serum hepcidin was significantly lower among iron reduced group. This result was opposing many studies as [1] that proved an increase in serum hepcidin level in iron deficient atheletes post exercise. The present study also against [4] and [13] results.

Since in the current study there was significant positive correlation between serum hepcidin and waist circumference in iron reduced group as [13] this proves the hypothesis that hepcidin is induced by the state of inflammation.

From the above statistical data we can explain why our results in serum hepcidin level weren't consistent with other studies and proving our hypothesis. All studies measured serum levels of hepcidin between $0 \mathrm{~h}$ and $6 \mathrm{~h}$ after the end of the exercise bout. The results were that exercise induces hepcidin increase in serum peaking at $\sim 3 \mathrm{~h}$ postexercise [1]. However our samples were withdrawn irrelevant of the exercise timing. 
Peeling et al., (2014) may also explain our results as their study showed pre-and $3 \mathrm{~h}$ postexercise hepcidin was sequentially greater as the groups baseline serum ferritin levels increased. The study results were that post-exercise hepcidin levels were only significantly elevated in three groups of reduced serum ferritin. An athlete's iron stores may dictate the baseline hepcidin levels and the magnitude of post-exercise hepcidin response. Low iron stores suppressed post-exercise hepcidin, seemingly overriding any inflammatory-driven increases.

\section{Conclusion:}

The present study showed positive correlation between CRP and BMI as well as positive correlation between hepcidin and waist circumference. However it didn't show any significant difference between the two studied groups regarding hepcidin level. This was related to the timing of sampling post exercise which may reveal the exact induction of hepcidin response to exercise and this may give guiding information on exact timing with iron therapy in athletes.

\section{References}

1- DOMÍNGUEZ R., SÁNCHEZ-OLIVER A.J., MATAORDOÑEZ F., et al.: Effects of an Acute Exercise Bout on Serum Hepcidin Levels. Nutrients, 10: p. 209-10, 2018.

2- DOMÍNGUEZ R., VICENTE-CAMPOS D., CHICHARRO J., et al.: Hepcidin Response to Exercise: Turk. Jem., 18: p84-91, 2014.

3- WORWOOD M.: Indicators of the iron status of populations: Ferritin. Assessing the iron status of populations, Second edition. Geneva, Switzerland. WHO, 2004.
4- PEELING P., SIM M., BADENHORST C., et al.: Iron Status and the Acute Post-Exercise Hepcidin Responsein Athletes, 9 (3): p. 166-70, 2014

5- HALLBERG L. and HULTHEN L.: High serum ferritin is not identical to high iron stores. America Journal of Clinical Nutrition, 78 (6): p. 1225-6, 2003.

6- FERRARI M., MISTURA L., PATTERSON E., et al.: Evaluation of iron status in European adolescents through biochemical iron indicators: The HELENA Study. Eur. J. Clin. Nutr., 65: p. 340-9, 2011.

7- SANDSTRÖM G., BÖRJESSON M. and RÖDJER S.: Iron Deficiency in Adolescent Female Athletes-Is Iron Status Affected by Regular Sporting Activity? Clin. J. Sport Med., 22: p. 495-500, 2012.

8- WALTERS G., MILLER F. and WORWOOD M.: Serum ferritin concentration and iron stores in normal subjects. J. Clin. Path. 6: p. 770-2, 1973.

9- DIGNASS A., FARRAG K. and STEIN J.: Imitations of Serum Ferritin in Diagnosing Iron Deficiency in Inflammatory Conditions Axel International Journal of Chronic Diseases, 93 (94): p. 60-3, 2018.

10- DEVARAJ S., SINGH U., JIALAL I., et al.: Human Creactive protein and the metabolic syndrome. Curr. Opin. Lipidol., 20 (3): p. 182-9, 2009.

11- HE H., WANG B., ZHOU M., et al.: Systemic Inflammation Mediates the Associations Between Abdominal Obesity Indices and Lung Function Decline in a Chinese General Population Diabetes, Metabolic Syndrome and Obesity: Targets and Therapy, 13: p. 146-8, 2020.

12- CHAPPELL M. and RIVELL S.: New potential players in hepcidin regulation. Haematologica, 104 (9): p. 311- 6, 2019.

13- NEMETH E., VALORE E.V., TERRITO M., et al.: Hepcidin, a putative mediator of anemia of inflammation, is a type II acute-phase protein. Blood, 101: p. 2461-3, 2003
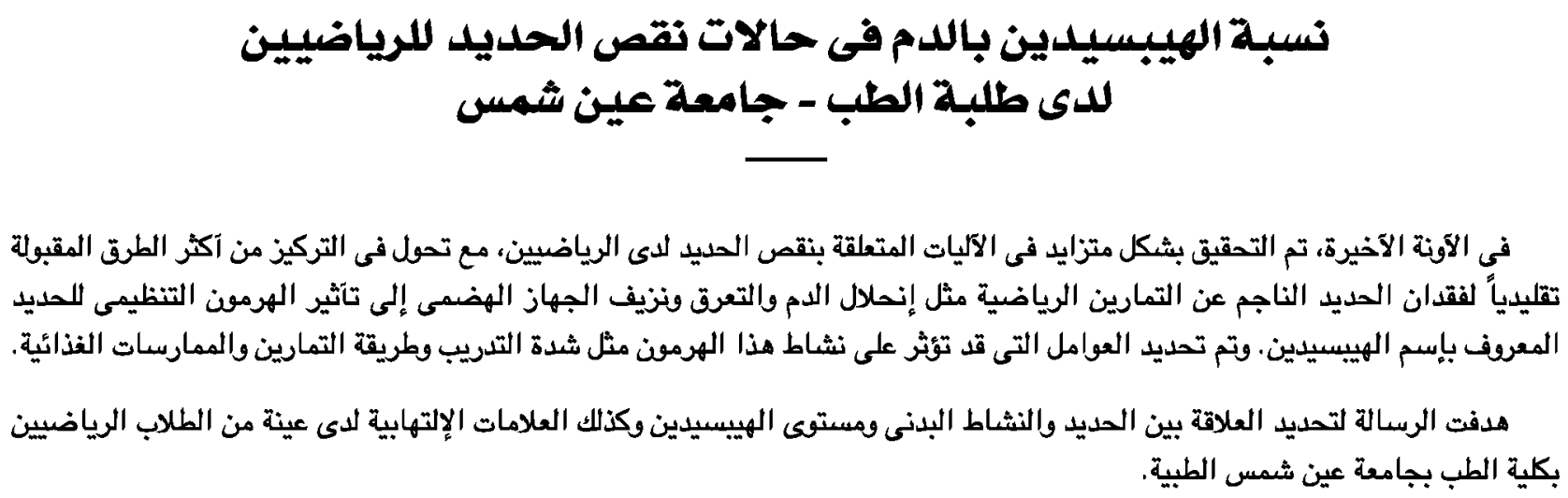